\title{
Research About Improvement the Aromatique Grapevine by Selection Clonale in the Vineyard Dealu Bujorului
}

\author{
Alina DONICI*, Florin BORA, Viorica ENACHE, Gabriel TABARANU \\ Research and Development Station for Vine and Winemaking Bujoru, Romania \\ *)Corresponding author, e-mail: donicialina79@gmail.com \\ BulletinUASVM Horticulture 73(2) / 2016 \\ Print ISSN 1843-5254, Electronic ISSN 1843-5394 \\ DOI:10.15835/buasvmcn-hort:12248
}

\begin{abstract}
The main objective of this paper is to present quality and uvologic parameters of two elites clonal 'Muscat Ottonel' 35-21, 'Şarbă 25-45' and two varieties 'Muscat Ottonel', 'Şarbă' for aromatic white wines cultivated in Dealu Bujorului vineyard. The highest weight of a grape was recorded in the 'Şarbă 25-45' (183 g) and the lowest was recorded in 'Muscat Ottonel' (93 g). The lowest index structure was recorded in 'Muscat Ottonel' (27.0) and the higher was registered in 'Muscat Ottonel 35-21'. The highest quality production was registered by 'Muscat Ottonel 35-21'. Regarding the technological indices of varieties analyzed, 'Muscat Ottonel 35-21' has the highest structure of the grape, berries composition and yield compared with all. The uvologic index for the analyzed varieties are within the specific intervals for varieties for aromatic white wines of superior quality.
\end{abstract}

Keywords: grapevine, selection clonal, vineyard

\section{Introduction}

The paper shows to orientation improvement program. Selection of varieties vine lead to avoiding the emergence of heterogeneous populations in terms of genotypic and phenotypic mixtures biotypes (ecotypes, agro-ecotypes), valuable or improper, affecting the quantity and quality of production. Selection clonale varieties will determine improve and expand the current range, in terms of quantity and quality of production, because each clone by cultural skills and quality that was selected (quantity, quality, mixed), contributes complementary to make production superior quality by adapting their culture at climatic conditions and specific vineyards and wine center in order to obtain wines with denomination of origin (Bora et al., 2015, 2014; Mureșan, 2008; Chun, 2005).

\section{Aims and objectives}

The main objective of this paper is to present quality and uvologic parameters of two elites clonal 'Muscat Ottonel' 35-21, 'Şarbă 25-45' and two varieties 'Muscat Ottonel', 'Şarbă' for aromatic white wines cultivated in Dealu Bujorului vineyard.

\section{Materials and methods}

The material used was the elites clonal 'Muscat Ottonel 35-21', 'Şarbă 25-45', and the grapevines 'Muscat Ottonel' and 'Şarbă varieties'. Agro biological and technological observations and measurements were performed in period 20132015. The statistical interpretation of the results was performed by DUNCAN test using SPSS version 20 .

\section{Results and Discussion}

Knowledge of the quality of the grapes is important to characterize the technological potential of varieties of vines. The highest weight of a grape was recorded in the 'Şarbă 25-45' (183 g) and the lowest was recorded in 'Muscat Ottonel (93 g). The lowest index structure was recorded in 'Muscat Ottonel' (27.0) and the higher was 
Tab.1. The quality production by varieties at SCDVV Bujoru mean for years 2013-2015 (mean \pm S.E. in g)

\begin{tabular}{|c|c|c|c|c|c|}
\hline Cultivar & $\begin{array}{c}\text { Average weight } \\
\text { of a grape bunch } \\
\text { (g) }\end{array}$ & $\begin{array}{c}\text { Weight of } 100 \\
\text { berries }(\mathrm{g})\end{array}$ & $\begin{array}{l}\text { Must sugar } \\
\text { content }(\mathrm{g} / \mathrm{L})\end{array}$ & $\begin{array}{c}\text { Total acidity } \\
\text { from must (g/ } \\
\left.\mathrm{H}_{2} \mathrm{SO}_{4}\right)\end{array}$ & $\begin{array}{c}\text { Average vine } \\
\text { production (kg/ } \\
\text { vine) }\end{array}$ \\
\hline 'Muscat Ottonel 35-21' & $129 \pm 1.0 \mathrm{~b}$ & $243 \pm 1 \mathrm{a}$ & $223 \pm 0.65 \mathrm{a}$ & $3.43 \pm 1 \mathrm{c}$ & $4.35 \pm 0.74 \mathrm{a}$ \\
\hline 'Muscat Ottonel' & $93 \pm 1.0 \mathrm{c}$ & $189 \pm 0.26 \mathrm{c}$ & $218 \pm 0.65 \mathrm{ab}$ & $2.6 \pm 1 \mathrm{~d}$ & $4.2 \pm 0.74 \mathrm{a}$ \\
\hline 'Şarbă 25-45' & $183 \pm 0.57 \mathrm{a}$ & $221 \pm 1 \mathrm{~b}$ & $201 \pm 0.76 \mathrm{bc}$ & $4.2 \pm 1 \mathrm{~b}$ & $2.2 \pm 0.28 \mathrm{~b}$ \\
\hline 'Şarbă' & $179 \pm 0.57 \mathrm{a}$ & $195 \pm 0.26 \mathrm{c}$ & $198 \pm 0.76 \mathrm{c}$ & $5.9 \pm 1 \mathrm{a}$ & $1.7 \pm 0.28 \mathrm{~b}$ \\
\hline Average & $146 \pm 2.14$ & $212 \pm 1.95$ & $210 \pm 3.41$ & $4.04 \pm 0,1$ & $3.13 \pm 0.14$ \\
\hline F (Fisher Factor) & 100.32 & 40.32 & 32.77 & 42.27 & 23.532 \\
\hline Sig. & $\mathrm{p} \leq 0.000$ & $\mathrm{p} \leq 0.000$ & $\mathrm{p} \leq 0.026$ & $\mathrm{p} \leq 0.000$ & $\mathrm{p} \leq 0.000$ \\
\hline
\end{tabular}

Tab.2. The technological indices of varieties analyzed mean for years 2013-2015 (mean \pm S.E. in g)

\begin{tabular}{cccccc}
\hline Cultivar & $\begin{array}{c}\text { Index structure } \\
\text { of the grape }\end{array}$ & $\begin{array}{c}\text { Index } \\
\text { berries }\end{array}$ & $\begin{array}{c}\text { Berries } \\
\text { composition } \\
\text { Index }\end{array}$ & Yield Index & Yield \% \\
\hline 'Muscat Ottonel 35-21 & $35.61 \pm 1 \mathrm{a}$ & $41.5 \pm 1 \mathrm{~b}$ & $6.4 \pm 1.0 \mathrm{a}$ & $2.1 \pm 0.4 \mathrm{a}$ & $67.3 \pm 0.13 \mathrm{a}$ \\
\hline 'Muscat Ottonel' & $27.0 \pm 1 \mathrm{c}$ & $37.0 \pm 1 \mathrm{c}$ & $4.5 \pm 0.3 \mathrm{~b}$ & $1.75 \pm 1 \mathrm{~b}$ & $61.6 \pm 1.0 \mathrm{c}$ \\
\hline 'Şarbă 25-45' & $31.3 \pm 0.5 \mathrm{~b}$ & $50.5 \pm 0.7 \mathrm{a}$ & $4.7 \pm 0.3 \mathrm{~b}$ & $2.1 \pm 0.4 \mathrm{a}$ & $66.2 \pm 0.13 \mathrm{ab}$ \\
\hline 'Şarbă' & $30.6 \pm 0.5 \mathrm{~b}$ & $50.2 \pm 0.7 \mathrm{a}$ & $4.3 \pm 0.3 \mathrm{~b}$ & $2.0 \pm 0.4 \mathrm{a}$ & $65.3 \pm 0.28 \mathrm{~b}$ \\
\hline Average & $\mathbf{3 1 . 1 5} \pm \mathbf{0 . 3 4}$ & $\mathbf{4 4 . 8} \pm \mathbf{0 . 2 9 6}$ & $\mathbf{1 4 . 9 8} \pm 0.123$ & $\mathbf{1 . 9 7 9 \pm 0 . 1 5}$ & $\mathbf{6 5 . 1 1 \pm 0 . 2 7 1}$ \\
\hline F (Fisher Factor) & 26.658 & 126.751 & 14.774 & 27.442 & 20.87 \\
\hline Sig. & $\mathrm{p} \leq 0.000$ & $\mathrm{p} \leq 0.000$ & $\mathrm{p} \leq 0.026$ & $\mathrm{p} \leq 0.000$ & $\mathrm{p} \leq 0.000$ \\
\hline 1. Average value \pm standard deviation (n=3). Different letters are significantly different for P $\leq 0.05$ between varieties. The \\
difference between any two values, followed by at least one common letter, is insignificant
\end{tabular}

registered in 'Muscat Ottonel 35-21'. The variety with the highest content in sugar of must was 'Muscat Ottonel 35-21' (223 g/L) and 'Şarbă' variety has the lowest content in sugar $(198 \mathrm{~g} / \mathrm{L})$ (Tab.1).

Based on the mechanical components of the grapes, the technological indices were calculated whose values complement the qualitative characteristics of a variety providing information on the direction of production - economic value and commercial. The lowest index structure of the grape was recorded in 'Muscat Ottonel' variety (27), while highest values elite clonal 'Muscat Ottonel 35-21' (35.61) followed by elite clonale 'Şarbă 25-45' (31.3) and 'Şarbă' variety (30.6). When analyzing the composition index of grapes it can be observed the lowest index was achieved in the 'Şarbă' (4). The highest berries index values was at elite clonale 'Şarbă 25-45' and 'Şarbă 'variety which shows that the berries are smaller.
The best yield in must was obtained in elite clonal 'Muscat Ottonel 35-21' (67\%) (Tab. 2).

\section{Conclusion}

The selection clonale 'Muscat Ottonel 3521 ' registered the highest quality production. Regarding the technological indices of varieties analyzed, elite clonal 'Muscat Ottonel 35-21' has the highest structure of the grape, berries composition and yield compared with all. The uvologic index for the analyzed varieties are within the specific intervals for varieties for aromatic white wines of superior quality.

\section{REFERENCES}

1. Bora FD, Pop TI, Babes AC, Popescu D, Iliescu M, Pop N (2015). Research on the quality of the three white wine varieties in transylvania, harvest of 2013-14. Bulletin UASVM Horticulture 70(2):327-334. 
2. Bora FD, Pop TI, Bunea CI, Peter A, Nicula C, Urcan DE, Babeș A, Pop N (2014). Physico-Mechanical Analysis and Uvological Indices at Three Varieties of Grapes for Superior White Wines Grown in North-West Romania. Bulletin UASVM Horticulture 72(2):337-338.
3. Mureșan C (2008). Wine Technology Applications Practice. Ed. Universității Aurel Vlaicu, Arad.

4. Chun OK (2005). Daily consumption of phenolics and total antioxidant capacity from fruit and vegetables in the American diet. J Sci Food Agric 85(2):1715-1724. 